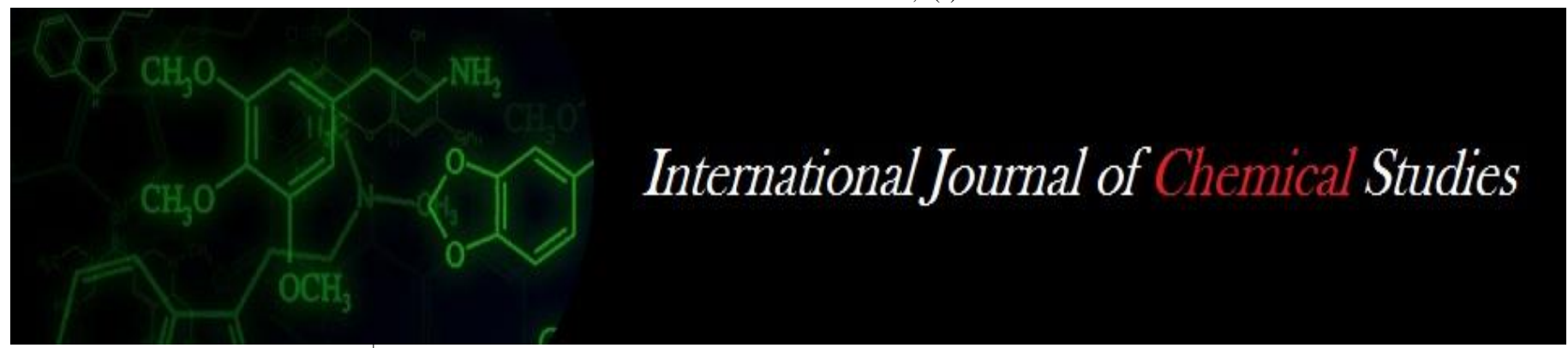

P-ISSN: 2349-8528

E-ISSN: 2321-4902

www.chemijournal.com

IJCS 2020; 8(5): 2643-2648

(C) 2020 IJCS

Received: 15-07-2020

Accepted: 17-08-2020

\section{Kanak Bhati}

Department of Genetics and

Plant Breeding, Navsari

Agricultural University,

Gujarat, India

DA Chauhan

Pulses and Castor Research

Station, Navsari Agricultural

University, Gujarat, India

Kajal C Rathod

Department of Genetics and

Plant Breeding, Navsari

Agricultural University, Gujarat,

India

\section{Aditi D Patel}

Department of Genetics and

Plant Breeding, Navsari

Agricultural University, Gujarat,

India
Corresponding Author:

Kanak Bhati

Department of Genetics and

Plant Breeding, Navsari

Agricultural University, Gujarat,

India

\section{A study of heterosis and inbreeding depression in Pigeon pea. (Cajanus cajan (L.) Mill spp)}

\author{
Kanak Bhati, DA Chauhan, Kajal C Rathod and Aditi D Patel
}

DOI: https://doi.org/10.22271/chemi.2020.v8.i5aj.10720

\title{
Abstract
}

The present investigation was conducted at Pulses and Castor Research Station, Navsari Agricultural University, Navsari during kharif 2017-20 with a view to study heterosis and other parameters of four crosses (each having $\mathrm{P}_{1}, \mathrm{P}_{2}, \mathrm{~F}_{1}, \mathrm{~F}_{2}, \mathrm{BC}_{1}$ and $\mathrm{BC}_{2}$ generations) in a Compact Family Block Design with three replications. Out of four crosses, cross II (GNP-401 X GNP-1B) and cross IV (GNP-401 x NPDK 15-12) recorded positive and highly significant relative heterosis and heterobeltiosis. Inbreeding depression was also recorded positive and significant in above mentioned crosses and values were $45.91 \%$ and $49.11 \%$ respectively. Relative heterosis value for cross II was $82.78 \%$ and for cross IV was $112.21 \%$. Heterobeltiosis value for cross II was $80.43 \%$ while, for cross IV was $13.64 \%$.

Keywords: Heterosis, Inbreeding depression, Relative Heterosis, Heterobeltiosis

\section{Introduction}

Legumes are one of the oldest cultivated crops. It is found in pre-historic records. Today they supply major nutrients second to cereals for a balanced human diet (Anonymous, 2011). Pigeon pea, a legume pulse crop, originated in India and spread to Africa, were it formed secondary centre of biodiversity. Cajanus cajanifolious, is the only progenitor of pigeon pea. It has a seed strophile which is only distinguishable morphological trait that differs it from cultivated pigeon pea. Pigeon pea is a diploid plant $(2 n=22)$ with a genome size of $852 \mathrm{Mbp}$. It is short lived woody perennial cultivated as annual crop in semi-arid tropical and subtropical regions of the world. Agronomically branching system in pigeon pea is classified as erect, semi-erect and spreading types. Protein content in commonly grown pigeon pea cultivars ranges between 17.9 to $24.3 \mathrm{~g}$ per $100 \mathrm{~g}$ for whole grain samples, and between 21.1 to $28.1 \mathrm{~g}$ per $100 \mathrm{~g}$ in the dal (Salunkhe et al., 1986) ${ }^{[14]}$. Regional name of pigeon pea in India are Toor in Hindi, thuvara paruppu in Malayalam, Kandhi pappu in Telugu, thuvaran paruppu in Tamil, Togari bele in Kannada. Diverse names used in world for pigeon are mu dou in Chinese, straucherbse in German, duvart in Swedish, cachito in Spanish, pois cajan or ambrevade in French and red gram, angola pea, congo pea, gungo pea in English. Global perspective shows that pigeon pea could be considered a promising pulse crop that is cable of providing nutritional food security. After chickpea, pigeon pea is most important pulse crop which is widely grown in the country. Major pigeon pea growing states are Gujarat, Andhra Pradesh, Maharashtra, Uttar Pradesh, Madhya Pradesh, Karnataka and Bihar. India is leading in world production of pigeon pea, but still couldn't meet the country demand. Thus, it is a need to develop hybrids or varieties with high productivity. The major constraints that limit the production of pigeon pea are non-availability of quality seeds of improved varieties in adequate quantity, poor crop management, biotic and abiotic stresses prevalent in the pigeon pea growing areas, besides socio-economic factors and narrow genetic base. Exploitation of hybrid vigour pigeon pea is important to increase its yield by 30-40 per cent (Singh, 2020) ${ }^{\text {[21], }}$ so study on heterosis so study on heterosis useful in deciding the direction of future breeding programme and to identify the promising cross combinations. Heterosis leads to increase in yield, reproductive ability, adaptability, disease and insect resistance, general vigour, quality etc.

\section{Materials and Methods}

The present investigation was carried out during kharif 2017-20, at Pulses and Castor Research 
Station, Navsari Agricultural University, Navsari. In this experiment six generations viz., $\mathrm{P}_{1}, \mathrm{P}_{2}, \mathrm{~F}_{1}, \mathrm{~F}_{2}, \mathrm{BC}_{1}$ and $\mathrm{BC}_{2}$ of four crosses involving four diverse genotypes of pigeon pea were used to study the genetic analysis of quantitative traits. Randomly selected ten competitive plants from each of the $\mathrm{P}_{1}$, $\mathrm{P}_{2}, \mathrm{~F}_{1}$, forty plants from $\mathrm{F}_{2}$ and twenty plants from each of the $\mathrm{BC}_{1}$ and $\mathrm{BC}_{2}$ generations were utilized per replication and observations were recorded on single plant basis for the following characters except days to maturity where, observations were made on plot basis.

\section{Estimation of heterosis}

Heterosis expressed as percent increase or decrease of $F_{1}$ hybrid over its mid-parent (relative heterosis) and over its better or superior parent (heterobeltiosis) were computed as follow:

$$
\begin{gathered}
\text { Heterosis }(\%)=\frac{\overline{\mathrm{F}}_{1}-\overline{\mathrm{MP}}}{\overline{\mathrm{MP}}} \times 100 \\
\text { Heterobeltiosis }(\%)=\frac{\overline{\mathrm{F}}_{1}-\overline{\mathrm{BP}}}{\overline{\mathrm{BP}}} \times 100
\end{gathered}
$$

Where,

$$
\begin{aligned}
\frac{\overline{F_{1}}}{\mathrm{MP}} & =\text { Mean performance of the } \mathrm{F}_{1} \text { hybrid } \\
\overline{\mathrm{BP}} & =\text { Mean value of the parents }\left(\mathrm{P}_{1} \text { and } \mathrm{P}_{2}\right) \text { of a hybrid }
\end{aligned}
$$

The standard errors and calculated ' $t$ ' value for test of significance for heterosis and heterobeltiosis were calculated as under:

\section{Standard errors}

$$
\begin{array}{cc}
\overline{\text { S.E }} . \overline{\left(\mathrm{F}_{1}-\mathrm{MP}\right)} & =\sqrt{3 \mathrm{Me} / \mathrm{r}} \\
\begin{array}{c}
\text { (Standard error for heterosis) } \\
\overline{\text { S.E. }} \overline{\left(\mathrm{F}_{1}-\mathrm{BP}\right)}
\end{array} & =\sqrt{2 \mathrm{Me} / \mathrm{r}} \\
\text { (Standard error for heterobeltiosis) } &
\end{array}
$$

Where,

$\mathrm{Me}=$ Error mean square

$r=$ Number of replications

't' test

$$
\begin{array}{lll}
\mathrm{t}\left(\mathrm{h}_{1}\right) & =\frac{\overline{\mathrm{F}}_{1}-\overline{\mathrm{MP}}}{\mathrm{S} \cdot \mathrm{E} \cdot\left(\overline{\mathrm{F}_{1}}-\overline{\mathrm{MP}}\right)} & \ldots . . \text { for relative heterosis } \\
\mathrm{t}\left(\mathrm{h}_{2}\right) & =\frac{\overline{\mathrm{F}}_{1}-\overline{\mathrm{BP}}}{\text { S. E. }\left(\overline{\mathrm{F}_{1}}-\overline{\mathrm{BP}}\right)} & \ldots . . . \text { for heterobeltiosis }
\end{array}
$$

The test of significance of the heterosis, heterobeltiosis and standard heterosis were carried out by comparing the calculated values of ' $\mathrm{t}$ ' with the tabulated values ' $\mathrm{t}$ ' at five percent (1.960) and one percent (2.576) levels of significance.

\section{Estimation of inbreeding depression}

Inbreeding depression was computed by using the following formulae:

$$
\text { Inbreeding depression }(\%)=\frac{\bar{F}_{1}-\bar{F}_{2}}{\bar{F}_{2}} \times 100
$$

The standard error and ' $t$ ' value for test of significance for inbreeding depression were estimated as under:

$$
\text { S.E. }\left(\bar{F}_{1}-\bar{F}_{2}\right)=\sqrt{\frac{\left[V\left(F_{1}\right)\left(n_{1}-1\right)\right]+\left[V\left(F_{2}\right)\left(n_{2}-1\right)\right]}{n_{1}+n_{2}-2}}
$$

$$
\mathrm{t}\left(\overline{\mathrm{F}}_{1}-\overline{\mathrm{F}}_{2}\right)=\frac{\overline{\mathrm{F}}_{1}-\overline{\mathrm{F}}_{2}}{\text { S.E. }\left(\overline{\mathrm{F}}_{1}-\overline{\mathrm{F}}_{2}\right)}
$$

Where,

$$
\begin{aligned}
& \overline{F_{1}}=\text { Mean value of the } \mathrm{F}_{1} \text { hybrid } \\
& \overline{F_{2}}=\text { Mean value of the } \mathrm{F}_{2} \text { generation } \\
& \mathrm{V}\left(\mathrm{F}_{1}\right)=\text { Variance of the } \mathrm{F}_{1} \text { generation } \\
& \mathrm{V}\left(\mathrm{F}_{2}\right)=\text { Variance of the } \mathrm{F}_{2} \text { generation } \\
& \mathrm{n}_{1}=\text { Number of observations in } \mathrm{F}_{1} \text { generation } \\
& \mathrm{n}_{2}=\text { Number of observations in } \mathrm{F}_{2} \text { generation }
\end{aligned}
$$

The significance of the inbreeding depression was tested by comparing the calculated ' $t$ ' value with the table ' $t$ ' value at 5 per cent (1.960) and 1 per cent (2.576) levels of significance.

\section{Result and Discussion}

The estimates of heterosis over mid parent value (relative heterosis) and over better parent (heterobeltiosis) in different $F_{1}$ hybrids and inbreeding depression in $F_{2}$ generation for various characters in four crosses of pigeon pea are presented in Table 1 and Table 2. Cross-I (GNP-401 x NPMK-14-01), cross-II (GNP-401 x GNP-1B), cross-III (GNP-401 x NPMK15-02) and cross-IV (GNP-401 x NPDK-15-12) here after referred to as cross-I, cross-II, cross-III and cross-IV, respectively, are presented and discussed character wise as below.

Grain yield per plant is a complex trait. Results in table 2 showed that the highly significant positive relative heterotic effects over mid-parental values was found in cross II $(82.78 \%)$ and cross IV (112.21\%) for trait grain yield per plant. Heterobeltiosis value was highly significant in all crosses with highest significant value in cross II $(80.43 \%)$ and cross IV (45.53\%). Positive significant inbreeding depression was found in cross II $(45.91 \%)$ and cross IV (49.11\%). For grain yield per plant, cross II and IV were considered better. Cross II showed significant heterobeltiosis (80.43\%) and significant relative heterosis $(82.78 \%)$. Cross IV, showed relative heterosis of 112.21 per cent which was high and along with that heterobeltiosis of 45.53 per cent. Similar result was obtained by Solomon et al. (1957) ${ }^{[25]}$, Sharma et al. (1973 a) ${ }^{[17]}$, Shrivastava et al. (1976) ${ }^{[19]}$, Saxena (1977) ${ }^{[15]}$, Reddy et al. (1979) [13], Venkateshwarlu et al. (1981) ${ }^{[28],}$ Jadhav and Narkar (1983) ${ }^{[4]}$, Sheriff and Subramanian (1983) ${ }^{[18]}$, Mareker (1985) [7], Saxena et al. (1986) ${ }^{[16], ~ S i n h a ~ e t ~ a l . ~}$ (1986) ${ }^{[24]}$, Patel et al. (1987) ${ }^{[10,11]}$, Cheralu et al. (1989) ${ }^{[3],}$ Singh et al. (1989) ${ }^{[20], ~ R a n a ~ e t ~ a l . ~(1990) ~}{ }^{[12]}$, Tuteja et al. (1992) ${ }^{[26]}$, Kumar et al. (2009a) ${ }^{[5]}$, Kumar et al. (2009b) ${ }^{[6],}$ Singh and Singh (2015) ${ }^{[22]}$ and Parmar and Kathiria (2016) ${ }^{[8,}$ 9].

The values of relative heterosis and heterobeltiosis is considered desirable in negative direction for days to first flowering, days to maturity and reproductive phase duration. For trait days to first flowering, estimates of heterobeltosis ranged from $-10.84 \%$ (cross I) to $-2.00 \%$ (cross II), which is considered desirable. Highly significant negative inbreeding depression was observed in cross II $(-7.38 \%)$ while highly significant positive inbreeding depression was observed in cross III $(3.21 \%)$. For trait days to maturity, out of four cross hybrids, cross I $(-2.73 \%)$ and cross III $(-8.39 \%)$ showed negative significant relative heterosis. All crosses, exhibited negative highly significant heterobeltiosis. The value of inbreeding depression was positive and significant in cross II $(8.23 \%)$ and cross IV $(3.43 \%)$ while other two crosses were non-significant. The data in Table 1 showed positive highly 
significant value for trait reproductive phase duration (days) in cross II, III and IV, while, cross I showed non-significant value of relative heterosis. Out of four crosses, cross II showed highly significant negative value for heterobeltiosis ($7.00 \%$ ) while other crosses were non-significant for trait reproductive phase duration.

Out of all crosses, for trait days to flowering, cross I was considered best, as, it showed negative relative heterosis and heterobeltiosis, inbreeding depression while other crosses showed negative inbreeding depression.

For days to maturity, cross II parents were considered most suitable as $F_{2}$ population matured earlier than $F_{1}$ population and $F_{1}$ hybrids matured earlier than earliest parent by 4.67 per cent. Thus, parents of this population have enough potential to be used in breeding programme were trait early maturity is of prime importance.

Out of four crosses, cross II is considered best. In this cross $\mathrm{F}_{2}$ population reproductive phase was much lower than $F_{1}$ reproductive phase $(9.40 \%)$ along with that $F_{1}$ hybrid had lower reproductive phase than its parent (better parent). Similar results were found by Solomon et al. (1957) [25], Veeraswamy et al. (1973) [27], Venkateshwarlu et al. (1981) ${ }^{[28]}$, Sheriff and Subramanian (1983) ${ }^{[18]}$, Sinha et al. (1986) [24], Cheralu et al. (1989) [3], Kumar et al. (2009a) ${ }^{\text {[5], Singh }}$ and Singh (2015) ${ }^{[22]}$ and Parmar and Kathiria $(2016)^{[8,9]}$

For trait, plant height $(\mathrm{cm})$ the value of heterosis over better parent was in the range $-6.57 \%$ (cross II) to $38.88 \%$ (cross IV). Out of four crosses, cross IV (28.89\%) showed positive highly significant heterobeltiosis. Only cross IV (19.24\%) showed positive highly significant value for inbreeding depression. Similar results were obtained by Solomon et al.

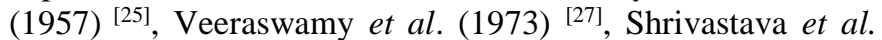
(1976) ${ }^{[19]}$, Sheriff and Subramanian (1983) ${ }^{[18]}$, Patel et al. (1987) ${ }^{[10,11]}$, Cheralu et al. (1989) ${ }^{[3]}$, Singh and Singh (2015) ${ }^{[22]}$. Heighted pigeon pea is non-desirable, because it causes lodging and breaking of stem, thus cross II is considered best, because its $F_{1}$ plants were lesser taller than its better parent by 11.79 per cent. But height is correlated with yield also, thus cross IV is also considered good when looked upon yield purpose.

It is pertinent to note that some hybrids of low $\mathrm{x}$ low and low $\mathrm{x}$ high yielding parents manifested relatively high heterobeltiosis while some hybrids involving high $\mathrm{x}$ high yielding parents exhibited low heterobeltiosis. The probable explanation for this type of behaviour is that poor yielding parents might have different constellations of genes with complementary action when brought together in a hybrid combination. It is therefore, desirable to select hybrid based on their mean performance rather than heterotic effect.

For trait primary branches per plant, out of four crosses only cross II (-12.67\%) showed significant negative relative heterosis for primary branches per plant. The estimates of heterobeltiosis were highly significant negative in cross II ($16.77 \%)$ and cross III $(-21.88 \%)$, while other two crosses were non-significant. Inbreeding depression ranged from $58.22 \%$ (cross IV) to $27.79 \%$ (cross II). Similar results were identified by Reddy (1979) ${ }^{[13]}$ and Saxena et al. (1986) ${ }^{[16]}$, Sinha et al. (1986) ${ }^{[24]}$, Singh et al. (1989) ${ }^{[20]}$, Kumar et al. (2009a) ${ }^{[5]}$, Kumar et al. (2009b) ${ }^{[6]}$, Singh and Singh (2015) ${ }^{[22]}$ and Bhanu et al. (2016) ${ }^{[2]}$;

None of the crosses $F_{1}$ hybrid had higher number of primary branches than its parents. Thus, judging on the basis of inbreeding depression, it was found that parents of cross IV, showed lowest inbreeding depression along with that primary branches were at par to better parent, and thus considered best among all crosses

The data embodied in table 1 indicated highly significant positive relative heterosis for trait secondary branches per plant in cross I $(35.18 \%)$ and cross II $(39.52 \%)$. Estimates of inbreeding depression were negative and significant in all crosses, except cross I (31.11\%), which showed positive value. Similar results were noted by Singh and Singh (2015) ${ }^{[22]}$. For Secondary branches per plant, parents of cross II were considered desirable because it showed highest relative heterosis.

The result tabulated in table 1 showed that heterosis over better parent for trait pods per plant were highly significant and positive for cross I $(10.08 \%)$, cross II $(39.68 \%)$, cross III $(23.71 \%)$ and cross IV (15.18\%). Heterobeltiosis value for cross II was only positive and significant $(25.82 \%)$, The value of inbreeding depression ranged from $19.19 \%$ (cross III) to $30.27 \%$ (cross IV). Similar results were obtained by Solomon et al. (1957) [25], Saxena (1977) [15], Venkateshwarlu et al. (1981) ${ }^{[28]}$, Singh et al. (1983), Saxena et al. (1986) ${ }^{[16]}$, Sinha et al.(1986) ${ }^{[24]}$, Singh et al. (1989) ${ }^{[20]}$, Tuteja et al. (1992) ${ }^{[26] \text {, }}$ Singh and Singh (2015) ${ }^{[22]}$. Out of four crosses, parents of cross II were considered desirable as it showed highest relative heterosis $(39.68 \%)$ and heterobeltiosis $(25.82 \%)$.

Out of four crosses, cross I $(7.21 \%)$ and cross IV $(9.79 \%)$ showed positive and significant relative heterosis for trait pod length. The value of heterobeltiosis was negative and highly significant in cross III $(-21.64 \%)$ and cross IV $(-11.30 \%)$, while non-significant in cross I $(-2.27 \%)$ and II $(0.00 \%)$. Estimates of inbreeding depression were significant and positive for cross III (10.11\%) and highly significant and positive in cross I $(5.85 \%)$. Cross II $(2.59 \%)$ and cross IV $(6.34 \%)$ were non-significant. Similar results were obtained by Singh and Singh (2015) ${ }^{[22]}$ and Parmar and Kathiria (2016) $[8,9]$. For trait pod length, cross IV, was considered best as it had highest relative heterosis and non-significant inbreeding depression

The value of relative heterosis were positive and significant in cross II $(23.61 \%)$, cross IV (14.07\%), cross I (12.5\%) for trait seeds per pod. The value of heterobeltiosis were positively significant in cross II $(3.49 \%)$ Out of four crosses, cross I, cross II and cross III showed positive significant inbreeding depression. Similar result was noted by Saxena (1977) ${ }^{[15]}$, Venkateshwarlu et al. (1981) ${ }^{[28]}$, Singh et al. (1983), Saxena et al. (1986) ${ }^{[16]}$, Sinha et al. (1986) ${ }^{[24]}$, Singh et al. (1989) ${ }^{[20] \text {, }}$ Tuteja et al. (1992) ${ }^{[26]}$, Singh and Singh (2015) ${ }^{[22]}$. Thus for trait seeds per pod, cross II was considered best of all crosses as it had high relative heterosis and heterobeltiosis.

The value for heterobeltiosis was highly significant positive in cross II $(3.56 \%)$ for trait 100 seed weight. Inbreeding depression ranged from $2.73 \%$ (cross IV) to $8.11 \%$ (cross I). Reddy et al. (1979) [13], Venkateshwarlu et al. (1981) ${ }^{[28],}$ Saxena et al. (1986) ${ }^{[16]}$, Sinha et al. (1986) ${ }^{[24]}$, Singh et al.

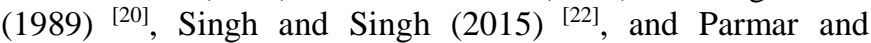
Kathiria $(2016)^{[8,9]}$. For trait 100 seed weight, cross IV was considered best because it showed higher seed weight $(3.56 \%)$ than it better parents. Along with that it also showed non-significant inbreeding depression.

The value for relative heterosis was highest in cross III (26.02\%) followed by cross II $(24.33 \%)$ and cross I (10.40) for trait leaf area $\left(\mathrm{cm}^{2}\right)$. Maximum heterobeltiosis was recorded by cross II (21.16\%) followed by cross III (13.64\%). Negative significant value of inbreeding depression was found in cross III (-24.16\%) and non-significant value in cross II. Cross II was considered good among all the crosses, 
because it had high heterobeltosis and relative heterosis values, while non-significant inbreeding depression.

Results in table 2 showed that the values of relative heterosis and heterobeltosis were non-significant in all the crosses for trait harvest index. Among the four crosses only cross IV $(4.47 \%)$ showed highly significant positive inbreeding depression. Similar results were obtained by Singh and Singh (2015) ${ }^{[22]}$ and Parmar and Kathiria (2016) ${ }^{[8,9]}$ for harvest index.
A perusal of data presented in table 2 indicated that the estimates of relative heterosis for this character ranged from $(0.24 \%)$ in cross II to $(2.42 \%)$ in cross IV for trait protein content. The value of heterobeltosis range from $(-1.40 \%)$ in cross II to $(1.90 \%)$ in cross IV. The value of relative heterosis and heterobeltosis were non-significant in all crosses. In $\mathrm{F}_{2}$ generation out of four crosses only one cross showed negative highly significant value of inbreeding depression in cross IV $(-3.21 \%)$. Similar results were obtained Reddy et al. (1979) ${ }^{[13]}$ and Singh et al. (1989) ${ }^{[20]}$.

Table 1: Estimates of relative heterosis (RH\%), heterobeltiosis (HB\%) and inbreeding depression (ID\%) for days to first flowering, days to maturity and reproductive phase duration (days), plant height $(\mathrm{cm})$, primary branches per plant, secondary branches per plant, pods per plant in four crosses of pigeon pea

\begin{tabular}{|c|c|c|c|c|c|c|}
\hline Character and cross & \multicolumn{2}{|c|}{$\mathbf{R H}(\%) \pm$ S.E } & \multicolumn{2}{|c|}{$\mathbf{H B}(\%) \pm \mathbf{S . E}$} & \multicolumn{2}{|c|}{ ID $(\%) \pm$ S.E } \\
\hline \multicolumn{7}{|c|}{ Days to first flowering } \\
\hline GNP-401 X NPMK-14-01 & \multicolumn{2}{|c|}{$-5.67 \pm 0.55$} & $-10.84 * *$ & \pm 0.55 & $-8.31 * *$ & \pm 0.74 \\
\hline GNP-401 X GNP-1B & \multicolumn{2}{|c|}{$5.11 * * \pm 0.54$} & $-2.00 * *$ & \pm 0.63 & $-7.38 * *$ & \pm 0.78 \\
\hline GNP-401 X NPMK-15-02 & \multicolumn{2}{|c|}{$-8.39 * * \pm 1.24$} & $-9.94 * *$ & \pm 1.25 & $-11.67 * *$ & \pm 1.32 \\
\hline GNP-401 X NPDK-15-12 & \multicolumn{2}{|c|}{$-0.98 * * \pm 0.32$} & $-6.88 * *$ & \pm 0.33 & $3.21 * *$ & \pm 0.48 \\
\hline \multicolumn{7}{|c|}{ Days to maturity } \\
\hline GNP-401 X NPMK-14-01 & $-2.73 * *$ & \pm 2.02 & $-5.29 * *$ & \pm 2.04 & -1.61 & \pm 2.16 \\
\hline GNP-401 X GNP-1B & $10.63 * *$ & \pm 0.77 & $-4.67 * *$ & \pm 0.98 & $8.23 * *$ & \pm 2.44 \\
\hline GNP-401 X NPMK-15-02 & -1.41 & \pm 1.62 & $-5.16^{* *}$ & \pm 1.64 & -0.81 & \pm 1.74 \\
\hline GNP-401 X NPDK-15-12 & $2.88^{*}$ & \pm 2.56 & $-2.92 * *$ & \pm 2.53 & $3.43 * *$ & \pm 2.85 \\
\hline \multicolumn{7}{|c|}{ Reproductive phase duration (days) } \\
\hline GNP-401 X NPMK-14-01 & 1.35 & \pm 2.06 & -0.34 & \pm 2.14 & $7.14 * *$ & \pm 2.22 \\
\hline GNP-401 X GNP-1B & $20.07 * *$ & \pm 0.92 & $-7.00 * *$ & \pm 1.09 & $9.40^{* *}$ & \pm 2.60 \\
\hline GNP-401 X NPMK-15-02 & $8.08 * *$ & \pm 2.09 & 1.01 & \pm 2.11 & $11.71 * *$ & \pm 2.22 \\
\hline GNP-401 X NPDK-15-12 & $8.07 * *$ & \pm 2.61 & 2.46 & \pm 2.58 & 3.70 & \pm 2.93 \\
\hline \multicolumn{7}{|c|}{ Plant height $(\mathrm{cm})$} \\
\hline GNP-401 X NPMK-14-01 & -3.85 & \pm 4.47 & $-11.68 * *$ & \pm 5.01 & 0.50 & \pm 4.31 \\
\hline GNP-401 X GNP-1B & $-6.57 *$ & \pm 4.22 & $-11.79 * *$ & \pm 4.78 & 4.15 & \pm 5.64 \\
\hline GNP-401 X NPMK-15-02 & 1.22 & \pm 7.23 & -2.95 & \pm 6.89 & -6.12 & \pm 6.96 \\
\hline GNP-401 X NPDK-15-12 & $38.88 * *$ & \pm 4.42 & $28.89 * *$ & \pm 4.36 & $19.24 * *$ & \pm 4.93 \\
\hline \multicolumn{7}{|c|}{ Primary branches per plant } \\
\hline GNP-401 X NPMK-14-01 & -2.42 & \pm 0.42 & -13.31 & \pm 0.59 & $-27.10 * *$ & \pm 0.41 \\
\hline GNP-401 X GNP-1B & $-12.67 *$ & \pm 0.50 & $-16.11^{* *}$ & \pm 0.52 & $27.79 * *$ & \pm 0.47 \\
\hline GNP-401 X NPMK-15-02 & 8.70 & \pm 0.54 & $-21.88 * *$ & \pm 0.57 & $-20.00 * *$ & \pm 0.66 \\
\hline GNP-401 X NPDK-15-12 & 3.02 & \pm 0.93 & -7.19 & \pm 0.99 & $-58.22 * *$ & \pm 1.12 \\
\hline \multicolumn{7}{|c|}{ Secondary branches per plant } \\
\hline GNP-401 X NPMK-14-01 & $35.18 * *$ & \pm 0.68 & -46.01 & \pm 1.03 & $31.11 * *$ & \pm 0.49 \\
\hline GNP-401 X GNP-1B & $39.52 * *$ & \pm 0.36 & $-47.95 * *$ & \pm 0.40 & $-31.3 \quad * *$ & \pm 0.38 \\
\hline GNP-401 X NPMK-15-02 & $-40.94 * *$ & \pm 0.40 & $-57.19 * *$ & \pm 0.59 & $-39.29 * *$ & \pm 0.46 \\
\hline GNP-401 X NPDK-15-12 & $-47.86 * *$ & \pm 0.34 & $-57.48 * *$ & \pm 0.44 & $-95.49 * *$ & \pm 0.32 \\
\hline \multicolumn{7}{|c|}{ Pods per plant } \\
\hline GNP-401 X NPMK-14-01 & $10.08 * *$ & \pm 13.95 & $-8.60 * *$ & \pm 18.59 & $30.27 * *$ & \pm 12.75 \\
\hline GNP-401 X GNP-1B & $39.68 * *$ & \pm 5.13 & $25.82 * *$ & \pm 07.56 & $28.31 * *$ & \pm 5.20 \\
\hline GNP-401 X NPMK-15-02 & $23.71 * *$ & \pm 10.50 & -0.94 & \pm 13.95 & $19.19 * *$ & \pm 11.94 \\
\hline GNP-401 X NPDK-15-12 & $15.18^{* *}$ & \pm 10.28 & $-18.27 * *$ & \pm 13.04 & $28.97 * *$ & \pm 13.06 \\
\hline
\end{tabular}

*- significant at $5 \%$ level of significance

**-significant at $1 \%$ level of significance

Table 2: Estimates of relative heterosis (RH\%), heterobeltiosis (HB\%) and inbreeding depression (ID\%) for pod length (cm), seeds per pod, 100 seed weight $(\mathrm{g})$, grain yield per plant $(\mathrm{g})$ and leaf area $\left(\mathrm{cm}^{2}\right)$, harvest index $(\%)$ and protein content $(\%)$ in four crosses of pigeon pea

\begin{tabular}{|c|c|c|c|c|c|c|}
\hline Character and cross & \multicolumn{2}{|c|}{ RH(\%) \pm S.E } & \multicolumn{2}{|c|}{$\mathrm{HB}(\%) \pm$ S.E } & \multicolumn{2}{|c|}{ ID $(\%) \pm$ S.E } \\
\hline \multicolumn{7}{|c|}{ Pod length $(\mathrm{cm})$} \\
\hline GNP-401 X NPMK-14-01 & $7.21 * *$ & \pm 0.12 & -2.27 & \pm 0.15 & $5.85 * *$ & \pm 0.15 \\
\hline GNP-401 X GNP-1B & 01.86 & \pm 0.11 & 0.00 & \pm 0.13 & 2.59 & \pm 0.11 \\
\hline GNP-401 X NPMK-15-02 & $-10.78^{*}$ & \pm 0.30 & $-21.64 * *$ & \pm 0.33 & $10.11^{*}$ & \pm 0.31 \\
\hline GNP-401 X NPDK-15-12 & $9.79 *$ & \pm 0.29 & $-11.30 * *$ & \pm 0.31 & 6.34 & \pm 0.29 \\
\hline \multicolumn{7}{|c|}{ Seeds per pod } \\
\hline GNP-401 X NPMK-14-01 & $12.5 * *$ & \pm 0.11 & -4.26 & \pm 0.13 & $10.74 * *$ & \pm 0.12 \\
\hline GNP-401 X GNP-1B & $23.61 * *$ & \pm 0.11 & $3.49 * *$ & \pm 0.13 & $10.11 * *$ & \pm 0.11 \\
\hline GNP-401 X NPMK-15-02 & $-24.69 * *$ & \pm 0.16 & $-37.81 * *$ & \pm 0.16 & $-30.00 * *$ & \pm 0.14 \\
\hline GNP-401 X NPDK-15-12 & $14.07 * *$ & \pm 0.19 & -6.67 & \pm 0.20 & -2.11 & \pm 0.21 \\
\hline \multicolumn{7}{|c|}{100 seed weight $(\mathrm{g})$} \\
\hline GNP-401 X NPMK-14-01 & $-2.37 *$ & \pm 0.11 & $-6.85^{* *}$ & \pm 0.12 & $8.11 * *$ & \pm 0.16 \\
\hline
\end{tabular}




\begin{tabular}{|c|c|c|c|c|c|c|}
\hline GNP-401 X GNP-1B & $-2.60 *$ & \pm 0.10 & $3.56^{* *}$ & \pm 0.11 & $4.96 * *$ & \pm 0.12 \\
\hline GNP-401 X NPMK-15-02 & 1.25 & \pm 0.10 & -0.21 & \pm 0.12 & 6.97 & \pm 0.11 \\
\hline GNP-401 X NPDK-15-12 & -0.68 & \pm 0.11 & -1.48 & \pm 0.12 & 2.73 & \pm 0.13 \\
\hline \multicolumn{7}{|c|}{ Grain yield per plant $(\mathrm{g})$} \\
\hline GNP-401 X NPMK-14-01 & 01.42 & \pm 2.19 & $-21.57 * *$ & \pm 2.81 & 7.02 & \pm 2.19 \\
\hline GNP-401 X GNP-1B & $82.78 * *$ & \pm 1.66 & $80.43 * *$ & \pm 1.93 & $45.91 * *$ & \pm 1.67 \\
\hline GNP-401 X NPMK-15-02 & $-60.83 * *$ & \pm 1.70 & $-70.47 * *$ & \pm 2.82 & $-94.72 * *$ & \pm 1.69 \\
\hline GNP-401 X NPDK-15-12 & $112.21 * *$ & \pm 5.56 & $45.53 * *$ & \pm 6.02 & $49.11 * *$ & \pm 5.90 \\
\hline \multicolumn{7}{|c|}{ Leaf area $\left(\mathrm{cm}^{2}\right)$} \\
\hline GNP-401 X NPMK-14-01 & $10.40 *$ & \pm 1.13 & 2.65 & \pm 2.64 & $13.86^{* *}$ & \pm 1.07 \\
\hline GNP-401 X GNP-1B & $24.33 * *$ & \pm 2.07 & $21.16^{* * *}$ & \pm 2.35 & -2.43 & \pm 2.01 \\
\hline GNP-401 X NPMK-15-02 & -03.99 & \pm 1.09 & $-11.20 *$ & \pm 1.54 & $-24.16 * *$ & \pm 1.02 \\
\hline GNP-401 X NPDK-15-12 & $26.02 * *$ & \pm 1.42 & $13.64 * *$ & \pm 1.31 & $17.89 * *$ & \pm 1.25 \\
\hline \multicolumn{7}{|c|}{ Harvest index $(\%)$} \\
\hline GNP-401 X NPMK-14-01 & 0.43 & \pm 1.09 & -1.44 & \pm 1.36 & 01.24 & \pm 0.19 \\
\hline GNP-401 X GNP-1B & $6.65 *$ & \pm 1.13 & -1.40 & \pm 1.37 & 0.53 & \pm 1.14 \\
\hline GNP-401 X NPMK-15-02 & -01.44 & \pm 0.52 & -1.56 & \pm 0.58 & $04.47 * *$ & \pm 0.68 \\
\hline GNP-401 X NPDK-15-12 & -0.80 & \pm 1.25 & -0.98 & \pm 1.37 & 02.15 & \pm 1.19 \\
\hline \multicolumn{7}{|c|}{ Protein content $(\%)$} \\
\hline GNP-401 X NPMK-14-01 & 0.61 & \pm 0.30 & -0.07 & \pm 0.32 & $-3.21 * *$ & \pm 0.23 \\
\hline GNP-401 X GNP-1B & 0.24 & \pm 0.25 & -1.40 & \pm 0.30 & -02.12 & \pm 0.23 \\
\hline GNP-401 X NPMK-15-02 & 1.30 & \pm 0.26 & 1.09 & \pm 0.29 & 0.04 & \pm 0.26 \\
\hline GNP-401 X NPDK-15-12 & 2.42 & \pm 0.35 & 1.90 & \pm 0.37 & 0.76 & \pm 0.35 \\
\hline
\end{tabular}

*- significant at $5 \%$ level of significance

**- significant at $1 \%$ level of significance

\section{Conclusion}

Highly significant and positive value for heterosis, heterobeltiosis and inbreeding depression were found in many crosses. Significant heterosis over mid-parent and better parent along with positive inbreeding depression may be attributed to major contribution from dominance (h) and additive $\times$ additive (i) gene effects, where selection will be effective only in latter generations. For grain yield per plant, the best heterotic crosses were cross II (GNP-401 x GNP-IB) and cross IV (GNP-401 x NPDK-15-12), For grain yield per plant, best of best, heterotic cross was cross IV (GNP-401 x NPDK 15-12), which also showed desirable significant negative relative heterosis for days to maturity, while desirable significant positive relative heterosis for plant height, pods per plant, pod length and leaf area. Thus, suitable breeding procedure which involves multiple crosses, biparental crosses would help in restoring desirable genes to get desirable segregants. This is especially important to develop good inbred lines having superiority of different characters.

\section{References}

1. Anonymous. ICRISAT, Annual Report, Patancheru, Andhra Pradesh, India 2011, 52, ISSN-1017-9933

2. Bhanu NA, Singh MN, Rathore AS, Hemantaranjan A, Saroj SK. Study of heterosis and inbreeding depression for yield attributing characters in Pigeon pea. The Journal of Plant Science Research 2016;32(2):143-148.

3. Cheralu C, Muralidhar V, Satyanarayan A, Venkateswarlu S. Heterosis in relation to combining ability in pigeonpea. Indian journal of agricultural sciences 1989;59(1):68-70.

4. Jadhav BD, Narkar YS. Heterosis for grain and yield in pigeon pea grown under different cropping systems. Indian Journal of Agricultural Sciences 1983;53(7):528531 .

5. Kumar CVS, Shreelaxmi CH, Shivani D, Suresh M. Identification of parents and hybrids for yield and its components using Line $\mathrm{X}$ Tester analysis in pigeon pea (Cajanus cajan (L.) Millsp.). Journal Research ANGRU 2009a;37(3, 4):65-70.
6. Kumar CVS, Shreelaxmi CH, Shivani D, Suresh M. Gene effects for yield contributing characters in pigeon pea (Cajanus cajan (L.). Millsp.). Journal Research ANGRU 2009b;37(3,4):71-76.

7. Mareker RV. Heterosis in pigeon pea. Indian Journal of Heredity 1985;17(3,4):5-11.

8. Parmar MB, Kathiria KB. Genetic analysis of seed yield and quantitative traits in pigeon pea. Global Journal for Research Analysis 2016;5(1):182-186.

9. Parmar MB, Kathiria KB. Genetic analysis of seed yield and quantitative traits in pigeon pea. Global Journal for Research Analysis 2016;5(1):182-186.

10. Patel JA, Pathak AR, Zaveri PP, Shah RM. Combining ability analysis in pigeon pea. Indian Journal of Genetics 1987;47(2):183-187.

11. Patel JA, Pathak AR, Zaveri PP, Shah RM. Combining ability analysis in pigeon pea. Indian Journal of Genetics 1987;47(2):183-187.

12. Rana SG. Analysis of genetic variation, heterosis and maintenance of male sterile line in pigeon pea. Unpublished M.Sc. (Agri.) thesis, Gujarat Agricultural University, Sardar Krishinagar 1990;51(2):208-213.

13. Reddy NP, Rao KV, Rao NGP. Heterosis and combining ability in pigeon pea. Indian Journal of Genetics 1979;39(2):240-246.

14. Salunkhe SK, Charan SS, Kadam, Reddy NR. Pigeonpea as an important food source. CRC Critical Review in food Science and Nutrition 1986;23(2):103-145.

15. Saxena KB. Evaluation of 28 parent diallel. In: "Pigeonpea Breeding. Annual Report. 1976-77, ICRISAT, India 1977, 121-144.

16. Saxena KB, Dwivedi S, Kumar RV, Faris DG. Performance of hybrid pigeon pea using wilt resistant male sterile C11 and BDN 1 lines. IPN 1986;5:21-23.

17. Sharma HK, Laxman Singh, Sharma D. Combining ability in diallel crosses of pigeon pea. Indian Journal of Agricultural Sciences 1973a;43(1):25-29.

18. Sheriff NM, Subramanian A. Genetic analysis of yield and yield components in red gram (Cajanus cajan (L) Millsp.). Madras Agricultural journal 1983;70(2):71-74. 
19. Shrivastava MP, Laxman Singh, Singh RP. Heterosis in pigeon pea. Indian Journal of Genetics 1976;36(32):197200.

20. Singh GP, Singh RM, Singh VP. Heterosis in pigeon pea hybrids. IPN 1989;10:6-8

21. Singh NP. Webinar (Revisiting strategy for Seelf sufficiency in Pulses: Introspection) organized by Indian Institute of Pulses, Kanpur.

(https://www.youtube.com/watch?v=qUzCKn2tOoI). 2020.

22. Singh RS, Singh MN. Heterosis and Inbreeding Depression for Yield and Yield Traits in Pigeon pea (Cajanus cajan L.). Environment \& Ecology 2015;34 (1A):395-399.

23. Singh SP, Gohil JN, Ras H. Combining ability and heterosis in early pigeon pea hybrids. India Journal of Genetics 1983;43:481-486.

24. Sinha SC, Shrivastava AN, Singh KN. Heterosis in relation to genetic divergenece in pigeonpea IPN, 1986;5:20-21.

25. Solomon S, Argikar GP, Solanki MS, Morbad TR. A study of heterosis in Cajanus cajan. Indian Journal of Genetics 1957;17:30-35.

26. Tuteja OP, Malik BPS, Singh VP. Heterosis in single and three way crosses in pigeon pea. Indian Journal of Genetics 1992;52(11):100-102.

27. Veeraswamy R, Rangaswamy P, Fazlullahkhan AK, Mohammed Shereef N. Heterosis in pigeonpea and the implications in producing hybrids on commercial basis. Madras Agricultural Journal 1973;68(8):496-501.

28. Venkateswarlu S, Singh RB. Combining ability in pigeon pea. Indian Journal of Genetics 1981;42(1):11-14. 